\title{
The experience of grandmothers in the care of the adolescent who consumes psychoactive substances
}

\author{
A experiência de avós no cuidado ao adolescente que consome substâncias psicoativas \\ La experiencia de las abuelas en el cuidado al adolescente que consume sustancias psicoactivas
}

\author{
Andressa Hithomi Takahara ${ }^{1}$ (D) \\ Sueli Aparecida Frari Galera² ${ }^{2}$ \\ Ana Carolina Guidorizzi Zanetti ${ }^{2}$ (i) \\ Angélica Martins de Souza Gonçalves ${ }^{1}$ (it) \\ Simone Terezinha Protti-Zanatta ${ }^{1}$ (D) \\ Sonia Regina Zerbetto ${ }^{1}$ (D)
}

1. Universidade Federal de São Carlos.

São Carlos, SP, Brasil.

2. Universidade de São Paulo.

Ribeirão Preto, SP, Brasil.

\section{Abstract}

Objective: To apprehend the experience of grandmothers who take care of their grandchildren who consume psychoactive substances. Methods: A descriptive study with a qualitative approach conducted with five grandmothers of two health services in a city in the interior of São Paulo. Data have collected from July 2015 to May 2016, through semi-structured interviews and analyzed using the technique of thematic content analysis. Results: The grandmothers recognized that their grandchildren used drugs when they changed their behavior, which required them to take on the role of counselor and educator. The aging process and financial difficulty consisted in limits to care. Conclusion and implications for practice: The grandmothers suffered psychosocial, structural, and organizational impacts, requiring nurses to enhance their facilitator skills in relational processes between two distinct generations of age and values.

Keywords: Family relations; Family; Adolescent; Substance-related disorders; Grandparents.

\section{Resumo}

Objetivo: Apreender a experiência de avós que cuidam de seus netos que consomem substâncias psicoativas. Método: Estudo descritivo, abordagem qualitativa, realizado com cinco avós de dois serviços de saúde de uma cidade do interior paulista. Os dados foram coletados no período de julho 2015 a maio 2016, por meio de entrevista semiestruturada e analisados pela técnica de Análise de Conteúdo Temática. O referencial teórico adotado foi a teoria sistêmica. Resultados: As avós reconheceram que os netos usaram drogas quando eles apresentaram mudança de comportamento, o que requereu delas assumirem pape de conselheira e educadora. O processo de envelhecimento e a dificuldade financeira consistiram em limites para o cuidado. Conclusão e implicações para a prática: As avós sofreram impactos psicossociais, estruturais e organizacionais, o que requer do enfermeiro, em sua prática clínica, aprimorar sua habilidade de facilitador nos processos relacionais entre duas gerações distintas em idade e valores.

Palavras-chave: Relações familiares; Família; Adolescente; Transtornos Relacionados ao Uso de Substâncias; Avós.

\section{Resumen}

Objetivo: Comprender la experiencia de abuelos que han cuidado de sus nietos que consumen sustancias psicoactivas Métodos: Estudio descriptivo, abordaje cualitativo, realizado con cinco abuelos de dos servicios de salud de una ciudad de interior del estado de São Paulo. Los datos fueron recolectados en el período de julio 2015 a mayo de 2016, por medio de entrevista semiestructurada y analizados por la técnica de Análisis de Contenido Temático. El referencial teórico adoptado fue la teoría sistémica. Resultados: Las abuelas reconocieron que los nietos usaron drogas cuando presentaron un cambio de comportamiento, lo que les requirió asumir el papel de consejera y educadora. El proceso de envejecimiento y la dificultad financiera consistieron en límites para el cuidado. Conclusión y implicación para la práctica: Las abuelas sufrieron impactos psicosociales, estructurales y organizacionales, requiriendo del enfermero mejorar su habilidad de facilitador en los procesos relacionales entre dos generaciones distintas en edad y valores.

Palabras clave: Relaciones familiares; Familia; Adolescente; Trastornos relacionados con sustancias; Abuelos.
Corresponding author:

Sonia Regina Zerbetto.

E-mail: szerbetto@hotmail.com

Submitted on $04 / 28 / 2018$

Accepted on 10/06/2018.

DOI: 10.1590/2177-9465-EAN-2018-0132 


\section{INTRODUCTION}

The consumption of drugs in the adolescence is one of the main challenge to public health worldwide. Thus, such consumption can significantly impact the life of the adolescent and its relatives, especially, in those members that have close affective ties and care. ${ }^{1}$ In general, the care of the drug addict is performed by the female figure, represented, mainly, by the mother, wife or grandmother. ${ }^{1}$

In the contemporary families, some grandmothers assume the role of the main caregivers of children and adolescents, ${ }^{2-4}$ including those who consume drugs. ${ }^{2,5}$ This role assumed by them can be associated with neglect and abandonment by the adolescents' parents, parents' death, parents'workload, ${ }^{2,5}$ socioeconomic and affective support. ${ }^{2-3,5}$ Other factors involve the closeness between the grandmothers and this specific population, by feelings of responsibility from them ${ }^{3}$ or by judicial orders. ${ }^{2,5}$

A literature review pointed out that only two national studies involved the grandmother's participation in the care process for her grandson in the event of sickness. ${ }^{6}$ Thus, there is a need to conduct studies that explore the grandmothers as the research participants and their experiences in this care, ${ }^{6}$ mainly the experience of these caregivers of adolescents drug user, considering the adversities and challenges that come from this experienced situation.

However, no study conducted until today addressed the grandmother's experience as caregiver of her grandsons children or adolescents who use psychoactive substances and, therefore, the present study is justified by providing the understanding of this new family structure and organization, apprehending the tasks and responsibilities assumed by them, as well as its difficulties. In this way, this study aimed to answer the following question: "How is the experience of grandmothers who care for her grandsons which are alcohol and other drug user?".

The object of this study was to apprehend the experience of grandmothers who care for her grandsons that consume psychoactive substances.

\section{METHOD}

Descriptive study, which used qualitative approach and based on system theory for data collection and analysis. In the systemic view, the family is understood as a system, in which their members interact, live together and share experiences and form affective ties and not only by the consanguinity. ${ }^{7}$ Therefore, event(s) occurred (s) with one of its components impact at varying intensities on all the members, as well as the family's reaction regarding the event $(\mathrm{s}) .^{7}$

The family, as a system, can divide into subsystems, such as, for example, grandson and grandmother, and, simultaneously, as part of a suprasystem (community, institutions, among others), represented by the context into which they are inserted and interacted for maintaining its completeness and functioning. ${ }^{7}$ The systems and subsystems are defined by limits constructed along values, beliefs and behavioral patterns (roles) made by each family member that helps to select elements that fit or not into that system. ${ }^{7}$

This study was conducted in two communitarian services of a city in the interior of the State of São Paulo, Brazil, between July 2015 and May 2016. The services involved were a Center of Psychosocial Attention Alcohol and Drugs (CAPS ad) and a Center of Clinical Specialties (CEME). These specialized services provide attendance and assistance to the population of adults, children and adolescents that have problems regarding drugs consumption or any mental disorder derived from this use. It underlines that, at the time of the data collection the child CAPS did not exist in the municipality.

With the help of the health professionals of the respective services, it was performed a survey of adolescents psychoactive substances user registered in the services and residing with the grandmothers. Nine participants had identified, of which three had already reached above 18 years old, and one of the grandmothers, however, has not recognized the problem of the drugs consumption of her grandson. Thus, the total of the intentional sample was made of five grandmothers of problematica adolescent psychoactive substances user on follow-up in these services, which respected the inclusion and exclusion criteria. Therefore, all the grandmothers registered and on follow-up in these services had interviewed by the responsible researcher. The inclusion criteria consisted of: to be biological grandmother or not of adolescent who consumed psychoactive substances (PAS), that lived with, grandmother with grandson, or grandson with grandmother; be the main caregiver and be cognitively able to understand and answer the questions. Exclusion criteria: the grandmother be psychoactive substancedependent, according to information from the health teams.

For the data collection, the first and last author of this article conducted semi-structured interviews, which were audio-recorded. The interviews occurred at home or in the own health service and last approximately 40 minutes. The interview script contained personal identification data of the grandmothers, labor condition, schooling, family configuration, economic situation and some guiding questions, such as: How is for you caring for your grandson (granddaughter) which use alcohol and other drugs? Which are the tasks that you perform in this care daily? How do you perceive your importance as caregiver of your grandson (granddaughter) in this family?

For the analysis, we used the thematic content analysis approach. ${ }^{8}$ The interviews were transcribe, read in depth and established some indicators to guide the codification and categorization process. The indicators used consisted of: meaning of the care, care and tasks developed, roles in the Family and importance of the grandmother in the care.

Following this step, the alphanumeric codification process occurred, considering the textual cuttings of the interviews in units of meaning, identifying themes and classifying the empirical categories. These categories were grouped and regrouped by themes correlated to the same semantic content or of implicit relevance. ${ }^{8}$ 
The last step involved inferences and interpretations. This phase consisted of apprehending the content actual or latent contained in the interviews, ${ }^{8}$ in a reflexive and critical manner, in order to relate them to the systemic theory and/or scientific evidences about the theme emerged.

The talks have identified with the word "Grandmother", followed by the sequential number of the interviews.

The study complied with the ethical aspects based on the Resolution CNS 466/2012, regulated by the Brazilian National Health Council, and was approved by the Research Ethics Committee on Human Beings according to protocol No. 971.409, at $10 / 03 / 2015$. The participants signed the Informed Consent Form.

\section{RESULTS}

Concerning the grandmothers' characterization the age group ranged between 60 and 74 years old, all of them were retired, the family income ranged between one or two minimum wages (value of the minimum wage at the time of the research: $R \$$ $880,00)$. Three of them were widows and Evangelical. Concerning the schooling level, the basic education has prevailed, being that two have not attended the school. Four grandmothers had the legal custody of the grandsons, justified by the psychoactive substances consumption by their biological genitors or even, prison or death of the same. Only one of them was not biological grandmother.

From the obtained data using the content analysis, four categories were elaborated: 1) Discovering the use of drugs: change in the behavior and attitude of the adolescent; 2) Assuming the advisory and educator role; 3 ) Dealing with the grandson under effect of the psychoactive substances; 4) Facing the limits of the care: the ageing and the financial problem.

\section{Discovering the use of drugs: change in the behavior and attitude of the adolescent}

This category addressed the issue of that the grandmothers of this study discovered the use of drugs by their grandsons, when they perceived changes in the behavior and attitude of the adolescents, mainly in the school context, regarding the group of friendships, the attitude of disobedience and involvement with robbery and trafficking.

The grandmothers' reports regarding the school context emphasized the receipt of complaints of teachers and directors regarding the attention difficulty of adolescents during the classes, the lack of compromise in the studies, frequent absences and aggressive behavior.

Then started [the adolescent] walking out early to go to school and did not go, missed school and stayed in the street. [...] The director says that he was very aggressive! [...] [the adolescent] was prevented from attending the classes (Grandmother 2).
Then started [the adolescent] going to school, play in the classroom, he did not want to do the things, I was called by the school. He came out [adolescent came out of the school]. I was called by the school, because he [adolescent] he was playing, he was altered, he started changing its way of being (Grandmother 1).

Considering the school as space that requires the adolescent to develop tasks, cognitive, behavioral and relational skills, and such fact can have facilitated that the grandmothers associate her grandsons' behavior changes with the psychoactive substances consumption. For them, the behaviors considered inappropriate result from the use of drugs.

In accordance with the followed talk, the grandmothers believed that the friends of their grandsons were bad companion and influenced them for the discovery and drugs consumption.

There were some girls in the school who were not good companions, he was getting involved and there he began [to use drugs] (Grandmother 4).

According to the perception of this grandmother, the bad companions in the school context were considered as risk factors for the psychoactive substances in the adolescence.

Other grandsons' behaviors observed by the grandmothers were the experience of living and sleeping on the street, as well as, the involvement with the trafficking, in accordance with the report below.

In a short time he began [the adolescent] to sleep on the street. She came home drunk. [...] Then she took more than 6 months, she [adolescent] got a bandit there and was to sell drug for other bandits (Grandmother 3).

For this grandmother, the drugs consumption was considered as a relevant factor so that her granddaughter looked for the street situation and the contact with the criminal world, by the drugs trafficking.

The grandmothers emphasized episodes of disobedience of her grandsons, differentiating from the behavior before the use of drugs, that is, obedient and loving. However, with the drugs consumption they began to do things without her consent, such as jump the wall of the house and go out at night, according to the following accounts:

Because I expected that he [adolescent] as he arrived. A good, obedient and softly boy [...] he changed in this rascal world (Grandmother 2).

At age 12, almost 13 [age of the adolescent]. Then, I only know that he started to go out without telling me, then I locked, he went out from the top, because the house has a wall, screwdriver until the top, isn't it. He went out from the top of the house (Grandmother 4). 
In the account of one of the grandmothers, another alteration of attitude of her grandson consisted of the involvement with robberies.

In addition, he [adolescent] began to steal, then this matter of cellular, even after he was small, before he stay running around the street (Grandmother 4).

In this grandmother 's perception, the consumption of drugs leads the adolescent to commit thefts, with thefts, to obtain financial resources for the sustenance of his use.

\section{Assuming the advisor and educator role}

The care provided in daily life by the grandmothers to their grandsons aimed at educating and instructing them. They were worried about feeding and personal hygiene, which due to consuming drugs, their grandsons have left to bath and feed regular and appropriately.

He [adolescent] took a bath, two to three times a day and was growing three to four days without taking a bath. (Grandmother 1).

The grandmothers also faced difficulties regarding the formal education of the grandsons, that is, they wished their grandsons would attend the school environment and would interest by the studies. Many times, in order to reach such objectives, they threatened them through compulsory hospitalization or loss of financial benefits received by them, such as, for example, the "Family allowance".

I enrolled him, he did not want to study; he went to school at the beginning of the classes, more or less, I think, five times. I speak: "Luana [fictitious name] go to school, Luana. The judge will not let you out of the school; you are going against the judge. The judge will hospitalize you" (Grandmother 3).

I spoke [grandmother]: "No, you will study; you need to study my son, because this benefit that you receive of the Family Allowance helps your mother helps you (Grandmother 1).

The counseling became the only strategy recognized by the grandmothers to face the grandsons' disobedience. Thus, they assumed the role of advisors trying to guide them and monitor them, mainly regarding the use of PAS. They tried to avoid that the same could leave home at night or could involve with companions que judged be harmful. The grandsons' disobedience has triggered signs of physical and emotional overload for the grandmothers, who thought many times about abandoning them or deliver the adolescent's custody to the Council of Guardianship.
Then I said in this way: "Your grandfather is angry, stop to do this [use of drugs]"; I started advising him, doesn't it: "For this thing it has only two 'options': cemetery or jail" (Grandmother 2).

He started leaving the home again, disobeying me. Why do I have the guardian of this boy? I went to the $t$ of Guardianship, I did this many times, for other things that he caused, then, I said: "I want to give the guardian back, because it's no use, I'm saving what? He does not obey me; he does not respect me, he left the house and I do not know where he is" (Grandmother 4).

\section{Dealing with the grandson under the effect of psychoactive substances}

With the living together, the grandmothers could identify the consumption of drugs by their grandsons through the change of behavior. The behavioral alterations involved conditions of de agitation and aggressiveness, breaking and robbery of objects home, death threats of relatives and of the own grandmother with white arms (knife and scissors).

One day he [adolescent] went out at 3 a.m., he arrived, he arrived insane, and he took a knife and threw into the girl [granddaughter]. I said: "Stop Roberto [fictitious name], what is this?" Then, he took the small scissors that was on the [table]; my girl woke up and saw the granddaughter spoke: "Run, mother [the granddaughter call the grandmother of mother] because he is with a scissors to drill you!" [...] it was when he began to break my things (Grandmother 1).

Other sign of recognition of drugs consumption was through change in the feeding habits and sleep pattern, that is, very hungry, intake a large amount of food, as well as sleep the whole day.

When he [adolescent] used, arrived with a bowed head, little hat "broken" [position of the flap downwards] [...] he came in and slept the whole day. He slept and ate; it was a large amount of the food in his plate, he ate the whole day (Grandmother 2).

The grandmothers felt perplexed, distressed, hopeless powerless not knowing how to do in the presence of a psychotic break of the adolescents. They reported that they suffered due to the disappearance of her grandsons, for days or weeks, without giving explanations, and many times involved with robberies or trafficking of drugs. The worry as a stressful factor for them, once, the lack of news of the whereabouts of the grandsons led them to suffer about the possibility of something bad could happen. 
I was in shock when I saw that [picture of the psychotic break]. I felt hopeless, distressed on seeing him [adolescent] in that situation. I stood there; we stay without reaction, because you do not know what to do. You can't do anything (Grandmother 1).

It's obvious, you worry, where he is, is sleeping, is eating. You are thinking [...] or vanished, disappeared, did any person throw him in the bush? [...] That hopelessness, do you know? (Grandmother 4)

In the face of a probable psychotic break of the grandsons due to use of PAS, the most interviewees told that they have no one to take care of their grandsons, counting on little or no help of relatives, such as, for example, the sons. They and the force arisen from God to face the difficulties inherent to drug consumption by their grandsons.

I had the God's force, isn't it? [...] my sons wanted to see me leaving my house, staying with them. I said: "You [sons] cannot help me; God will give me the force". However, this (daughter) is the unique who does what he can do for me. Because the remainder, only know how to criticize me (Grandmother 1).

\section{Facing the care limits: the ageing and the financial problem}

The grandmothers attributed to the ageing and chronic diseases the difficulties that face to educate and monitor the grandsons drug users. However, they believed that the stress caused by the chemical dependence of the grandsons have aggravated their state of health.

I have this age, full of "parrots beak" [arthrosis], with diabetes, high pressure, cholesterol, all on me. [...] it's because each day I feel nervous, of we are speaking with the person and it does not listen [...] I speak, I will not go after. When I know that he is in the square, I already went there two times to search (Grandmother 3).

Another limitation pointed out referred to financial problems resulted from the robberies committed by the grandsons to obtain the drugs.

There were day when he [adolescent] robbed me, leave me without any money, not even to buy bread. Then, I know that I was getting involved with debts in the bank, then, he robbed my debit card, isn't it? However, he did never have my password before; he had never done it, before. Then, he used the card; he bought a cellular, bought a video game (Grandmother 4).

\section{DISCUSSION}

The grandmothers of this study assumed the legal responsibilities, roles and tasks to take care of their grandsons, since the birth or in the pre scholar and scholar of them, due to critical situations experienced by their genitors. Such adversities required them, the need to restructure and organize their lives, assuming many times the role of "mothers".

In the systemic view, considering the concepts of the coexistence of changes and stability and of the hierarchical systems theory, it can see that the grandmother on assuming the legal guardian of the grandson (granddaughter) goes through an event that destabilizes the functionality of the family as a system. Faced with, they organize as a way of reestablishing the balance of the family system, which is dynamic not static, that will require to expand their limits and borders in taking a new role in this family, now as main caregivers. ${ }^{7}$

It was understood that the consumption of psychoactive substances by the genitors could affect their cognitive, affective and behavioral capacity, preventing them in some moments from taking care of their sons, and consequently leading them to neglect these children or adolescents. In addition, the chemical dependence context can promote the involvement of these parents with the trafficking and robberies, causing their prison. Study carried out with grandmothers who assume the creation of grandsons indicates that is common among the reasons that led them to assume such responsibility, the use of alcohol and other drugs and the negligence by the genitors. ${ }^{2,5}$

In the first category, the discovery of the grandmothers about the use of drugs by their grandsons was evidenced by behavioral changes, that is, of obedient and affective to confrontational children and disobedient, corroborating the literature. ${ }^{9-10}$ These attitudes can be inherent to the moment of the vital cycle experienced by the grandsons, that can involve intense questions originated in the search of the personal and social identity, that are characteristics of the adolescence. However, the use of PAS can accentuate the facing attitude of authority presented by the adolescents.

Other changes in the behavior of the grandsons referred to problems in the school performance and aggressiveness in the school and at home. It was understood that the drugs consumption may have caused an increase in missing school, reduction of the attention in classes, prejudicing the school performance of the adolescent. Such situation can incite reprimand behaviors by teachers and directors, culminating in aggressive and challenging authority behaviors by the adolescent. Study points that the leaving school due to the involvement in conflicts situations is more frequent among young user of PAS. ${ }^{11-13}$

Linked to the factors abovementioned, the bad companions have recognized by the grandmothers as risk factors to the use of drugs and change of behavior. Studies with close family members to user of illicit drugs point out the influence of the risk environment and problematic friendships as predisposing factors for the consumption. ${ }^{1,14}$ 
In the systemic view, the presence of crisis in the relationship between grandmother and the grandson can trigger in the adolescent the need to search external alliances to the family nucleus, configuring in positive or negative triangulation. The positive triangulation occurs when two or more family members or not, come together to help the adolescent. The negative corresponds to a union between two members against a third, and can exclude him, ignore him or damaging him. Thus, in the grandson's perception, in general, the group of friends user of drugs understand him better than it understand its relatives that may configure in a negative triangulation.

The data also pointed out the grandsons' involvement with robberies and trafficking of PAS, what is frequently associated with the need for the adolescents to obtain financial resources for the maintenance of its consumption of drugs. The adolescent when being chosen for the trafficking of drugs believe that he obtained a social status in the world of crime and opportunity to have access to the drug. In the systemic perspective, such beliefs and behaviors arise from an interactional and circular process, ${ }^{7}$ that includes both the adolescent and the grandmothers, which are inserted in more wide systems, that involve social, political, economic and cultural aspects that impact them and stimulate them to the answers in different situations.

However, national studies problematize the relation between infractional act and drugs consumption in the adolescence. ${ }^{15-16}$ As determinant factors for such act, integrative review considers the heterogeneity of this specific population (social class, ethnicity, schooling level $)^{16}$ and other study, the existence of social determinants for the act of committing delinquency and not only personal decision to the consumption of drugs. ${ }^{15}$ However, in the context of the drugs addiction, this adolescent experiences vulnerable situations, such as the violence, taking roles of aggressor or victims, which requires public policies of protection to this specific population. ${ }^{17-18}$

Regarding the role of advisors and educators, pointed out in the second category, the approaches of the grandmothers have related to the worry with the feeding and hygiene, triggering harm to the grandsons' health caused by the drugs consumption. Other apprehension that required from the grandmothers taking such social roles, involved the follow-up of the formal education of their grandsons, monitoring them as to the use of PAS, their parties and to the grandsons' attitudes of disobedience, which showed affective and informative support.

These findings corroborated study that points out that abusive consumption of psychoactive substances interfere in the daily and scholar habits of the adolescent, triggering sleepiness or insomnia, thinness and carelessness with the physical appearance, as well as evasion and school delay..$^{13}$ The grandmothers recognized that such behaviors arose from the drugs addiction and tried to manage and resolve such questions by themselves, through counselling and orientations.

However, studies with grandmothers who take care of their grandsons emphasize that such care are inherent to the social role of caregiver, since involve attributions related to the grandsons' instruction and socialization. ${ }^{2,4,19-20}$
Such role, which should be play by the parents, deprives the grandmother of performing activities that would be genuinely of her, as providing moments of leisure, plays and changes of experience. ${ }^{19-20}$

Such change of roles identified in this study, associated with the grandsons' disobedience and behavioral alterations arising from the drugs, evidenced physical and emotional overload in the grandmothers, causing feelings of hopelessness and attempts to abdicate her legal responsibilities related to the grandsons. In accordance with these findings, studies point out that these feelings of weakness and tiredness of caregivers of drugs user are recognized and configured in a co-dependencyb, in the view of the disease model. ${ }^{21-23}$

In the systemic view, however, it can infer the existence of negative circularity in the relationship between counseling of grandmother and disobedience of grandson, intensified in the chemical dependency context. The behavior of the grandmother influence in the challenging authority behaviors on the grandson's attitudes, which shows increasingly disobedient when the grandmother requires him the change of daily habits. The more she requires, the more disobedient he becomes, which interferes in the grandmother's approach and intensify their physical and emotional overload signs.

It emphasizes that, both the grandmother and the adolescent need of the aid of qualified professionals into the drugs and family thematic, to help them in the therapeutic process and the management of the situation. In the systemic perspective, the interventions of the health team require identifying hypotheses in the affective, thinking and behavioral domains that pass by this relational circularity, so that the combination can also identify its individual and collective health needs, as well as opportunities of growing and changes.

In the third category, related to the way how the grandmothers deal with the grandson under the effect of psychoactive substances, it involved feeling of impotence in the management of hostility episodes, verbal threatening and physical violence arisen from their grandsons, corroborating study carried out. ${ }^{23}$ The data were also confirmed by the literature that approaches the perception of the caregivers of drug users, that involve fear of the unknown, due to the absence of knowledge and management of the situation. ${ }^{24}$

The care process of the grandmothers in front of the effects of this consumption triggered emotional suffering and worry in the grandmothers in front of the frequent disappearance and experience of street of their grandsons. Such situations caused them attitudes of monitoring and search of their grandsons, due to the exposition of these to the risk situations.

The frequent grandmothers 'experience in situations of intimidation and physical and psychological violence, worry with the well -being and safety of the adolescents triggered stressing sensations, manifested by feelings of impotence and desperation, converging with the literature. ${ }^{23,25}$ In front of the lack of support by other family members during episodes of behavioral alteration of the grandsons due to the drug effects, the grandmothers obtained forces in her Divine faith. Studies 
with similar results identified the religiosity as a resource for the facing of this situation, mainly through the prayers. ${ }^{24,26}$

The last category pointed out that the ageing and the fragile health were recognized by the grandmothers as difficult factors for the care, the follow-up of the formal education of their grandsons psychoactive substances users and the possibility of monitoring them in their excursions for the drugs consumption, considering that all the grandmothers in this study were aged. Such data corroborated a study about the experience of the grandmothers that take care of their grandsons, which points out the reduction of the physical vitality, difficulties in the school follow-up and in other care of their grandsons, arisen from the ageing process. ${ }^{20}$

Despite the literature point that at present the grandmothers have taken responsibilities that were attributed socially to the genitors, ${ }^{2}$ the specificities lived by the participants in this study infer that they need to be cared rather than take caring of. Study points that advanced age and undermined health constitute negative experiences, mainly regarding the future of their grandsons, considering the grievance of the morbidity and the risk of death. ${ }^{2}$

The data of this study pointed the living of the grandmothers with chronical diseases, such as diabetes and arterial hypertension, aggravated by the stress originated from the tension situations due to the use of PAS by the adolescents. Studies strengthened the grievance of these chronic diseases, in addition to the declining in the health state, in grandmothers who take care of her grandsons, attributed to the increase of the responsibilities inherent to the care. ${ }^{27-28}$

Regarding the financial questions, the grandmothers in this study faced obstacles arisen from home robberies from their own grandson (granddaughter) in search of money to the drug addiction or debts payment, strengthened by other research. ${ }^{23}$ The financial impact in the life of the grandmothers who took the legal responsibility by their grandsons was identified in previous studies $^{2,20}$ which point out economic overload as a negative aspect of the responsibilities inherent to the care of the grandsons.

The limitation of this study referred only to the apprehension of the aged grandmother' experience only. Such fact could have influenced in the way of taking care of the grandmothers, considering the differences existing among generations that is, regarding the wide difference of age, life experiences and values apprehended between the grandmothers and their grandsons.

\section{CONCLUSIONS AND IMPLICATIONS FOR PRACTICE}

This study made it possible to apprehend that the grandmothers and her relatives suffered impact by the changes arisen from the chemical dependence context and searched for facing strategies, which consisted of the family reorganization.

The grandmothers in taking the role of caregiver, educator and advisor of their grandsons attributed tasks to themselves that associated with the critical moments of the psychoactive substances effects triggered physical, emotional and economic overload. Such overloads were intensified by the physical limitation, justified by the natural process of ageing and chronic diseases.

This study contributes to the reflection on the psychosocial, structural and organizational impacts in the relationship between the aged grandmother and their grandsons in the drugs context, and requires future studies in this thematic, apprehending the view of both the health professional and the grandsons, in the systemic perspective.

The impact of this study for nursing relates to the need to improve the ability of this professional as facilitator in the relational processes between two distinct generations, many times with a wide age difference, of moral and cultural values. Such aspect can intensify the conflicts, which not always related only to the use of the psychoactive substance.

\section{REFERENCES}

1. Siqueira DF, Moreschi C, Backes DS, Terra MG, Soccol KLS, Mostardeiro SCTS. Perception of family about the initiation of the use of crack for adolescent. Ciênc Cuid Saúde [Internet]. 2015 Jan/Mar; [cited 2016 Feb 23]; 14(1):948-54. Available from: http://periodicos.uem.br/ojs/index. php/CiencCuidSaude/article/view/23019/14216. DOI: http://dx.doi. org/10.4025/cienccuidsaude.v14i1.23019

2. Mainetti AC, Wanderbroocke ACNS. Avós que Assumem a Criação de Netos. Pensando Fam [Internet]. 2013 Jul; [cited 2016 Feb 23]; 17(1):87-98. Available from: http://pepsic.bvsalud.org/pdf/penf/v17n1/v17n1a09.pdf

3. Silva DM, Vilela ABA, Nery AA, Duarte ACS, Alves MR, Meira SS Dynamics of intergenerational family relationships from the viewpoint of elderly residents in the city of Jequié (Bahia), Brazil. Ciênc Saúde Coletiva [Internet]. 2015 Jul; [cited 2017 Apr 9]; 20(7):2183-191. Available from: $\mathrm{http}: / / \mathrm{dx}$.doi.org/10.1590/1413-81232015207.17972014

4. Cardoso AR, Brito LMT. Ser avó na família contemporânea: que jeito é esse? Psico-USF [Internet]. 2014 Sep/Dec [cited 2016 Feb 23]; 19(3):433-41. Available from: http://dx.doi.org/10.1590/141382712014019003006

5. Coelho MTBF, Dias CMSB. Avós guardiões: uma revisão sistemática de literatura do período de 2004 a 2014. Psic Teor Pesq [Internet] 2016; [cited 2017 Feb 1]; 32(4):e324214. Available from: http://www. scielo.br/scielo.php?pid=S0102-37722016000400214\&script=sci_ abstract\&tlng=pt

6. Mendes-Castilho AMC, Bousso RS. The grandparents of sick children a new perspective for research with families in Brazil. REME Rev Min Enferm [Internet]. 2015 Jul/Sep; [cited 2017 Apr 9]; 19(3):793-6. Available from: http://dx.doi.org/10.5935/1415-2762.20150060

7. Wright LM, Leahey M. Enfermeiras e famílias: guia para avaliação e intervenção na família. Tradução de Silvia Spada. 5aㅡ ed. São Paulo: Roca; 2012.

8. Minayo MCS. O desafio do conhecimento: pesquisa qualitativa em saúde. 14ª ed. São Paulo: Hucitec; 2014.

9. Figlie NB, Bordin S, Laranjeira R, orgs. Aconselhamento em dependência química. $2^{\mathrm{a}}$ ed. S. Paulo: Roca; 2010.

10. Bessa MA, Boarati MA, Scivoletto S. Crianças e adolescentes. In: Diehl $A$, Cordeiro DC, Laranjeira R, orgs. Dependência química: prevenção, tratamento e políticas públicas. Porto Alegre: Artmed; 2011. p. 359-74.

11. Kelly AB, Evans-Whipp TJ, Smith R, Chan GCK, Toumbourou JW, Patton GC, et al. A longitudinal study of the association of adolescent polydrug use, alcohol use and high school non-completion. Addiction [Internet]. 2014; [cited 2017 Apr 9]; 110(4):627-35. Available from: http:// onlinelibrary.wiley.com/doi/10.1111/add.12829/pdf 
12. Choate PW. Adolescent Alcoholism and Drug Addiction: The Experience of Parents. Behav Sci (Basel) [Internet]. 2015 Oct; [cited 2017 Apr 9]; 5(4):461-76. Available from: https://www.ncbi.nlm.nih.gov/ pubmed/26529024

13. Moura NA, Monteiro ARM, Freitas RJM. Adolescents using (il)licit drugs and acts of violence. J Nurs UFPE On Line [Internet]. 2016 May [cited 2017 Apr 9]; 10(5):1685-93. Available from: https://periodicos.ufpe.br/ revistas/revistaenfermagem/article/view/13543/16313

14. Seleghim MR, Inoue KC, Santos JAT, Oliveira MLF. Aspectos da estrutura familiar de jovens usuários de crack: um estudo do genograma. Ciênc Cuid Saúde [Internet]. 2011; [cited 2017 Apr 9]; 10(4):795-802. Available from: http://www.periodicos.uem.br/ojs/index. php/CiencCuidSaude/article/view/18325/pdf

15. Pereira PE, Malfitano APS. Atrás da Cortina de Fumaça: Jovens da Periferia e a Temática das Drogas. Saúde Transform Soc. [Internet]. 2014; [cited 2017 Apr 9]; 5(1):27-35. Available from: http://pepsic. bvsalud.org/pdf/sts/v5n1/5n1a06.pdf

16. Jiménez L, Meireles Andrade E, Batistella Bianchini LG. Uso de drogas e ato infracional: Revisão integrativa de artigos brasileiros. Rev Latinoam Cienc Soc Niñez Juv [Internet]. 2016; [cited 2017 Apr 9]; 14(2):939-55. Available from: http://www.scielo.org.co/pdf/rlcs/v14n2/v14n2a05.pdf

17. Santos LIC, Oliveira AM, Paiva IL, Yamamoto OH. Juventude e violência: trajetória de vida e políticas públicas. Estud Pesq Psicol [Internet]. 2012 Aug; [cited 2015 Jan 14]; 12(2):521-38. Available from: http://pepsic. bvsalud.org/pdf/epp/v12n2/v12n2a12.pdf

18. Reis DC, Almeida TAC, Coelho AB, Madeira AMF, Paulo IMA, Alves RH. Estratégia saúde da família: atenção à saúde e vulnerabilidades na adolescência. Espaç Saúde (Online) [Internet]. 2014 Apr; [cited 2015 Jan 14]; 15(1):47-56. Available from: http://bases.bireme.br/cgi-bin/wxislind. exe/iah/online/?IsisScript=iah/iah.xis\&src=google\&base=LILACS\&lang $=p \&$ nextAction=Ink\&exprSearch=723486\&indexSearch=ID

19. Alves SMM. Cuidar ou ser responsável? Uma análise sobre a intergeracionalidade na relação avós e netos [tese]. Fortaleza: Centro de Estudos Sociais Aplicados, Universidade Estadual do Ceará;2013.

20. Cavalcanti JRG, Vieira KFL, Amaral DH, Sousa V, Cardoso DB. Percepções e vivências de avós que cuidam de seus netos. In: Anais $\mathrm{CIEH}$. 4ํㅡㄹ Congresso Internacional de Envelhecimento Humano; 2015 Set 21-26; João Pessoa, PB, Brasil. João Pessoa Anais Centro Universitário de João Pessoa - UNIPÊ; 2015. p. 2318.
21. Medeiros KT, Maciel SC, Sousa PF, Tenório-Souza FM, Dias CCV. Representações sociais do uso e abuso de drogas entre familiares de usuários. Psicol Estud [Internet]. 2013 Apr/Jun; [cited 2015 Dec 3]; 18(2):269-79. Available from: http://www.scielo.br/pdf/pe/v18n2/ a08v18n2.pdf

22. Soccol KLS, Terra MG, Ribeiro DB, Mostardeiro SCTS, Teixeira JKS, Souto VT, et al. Sobrecarga financeira vivenciada por familiares cuidadores de indivíduos dependentes químicos. Rev Enferm UFSM [Internet]. $2014 \mathrm{Jul} / \mathrm{Sep}$; [cited 2015 Dec 3]; 4(3):602-11. Available from: https://periodicos.ufsm.br/reufsm/article/view/11264/pdf

23. Groenewald C, Bhana A. "It was Bad to See My [Child] Doing this": Mothers' Experiences of Living with Adolescents with Substance Abuse Problems. Int J Ment Health Addiction [Internet]. 2016 Oct;14(5):646-61 Available from: https://link.springer.com/article/10.1007/s11469-0159605-7

24. Pegoraro RF, Caldana RHL. Sobrecarga de familiares de usuários de um centro de atenção psicossocial. Psicol Estud [Internet]. $2006 \mathrm{Sep} /$ Dec; [cited 2017 Jan 14]; 11(3):569-77. Available from: http://www. scielo.br/pdf/pe/v11n3/v11n3a12.pdf

25. Asante KO, Lentoor AG. Use of crystal methamphetamine among male adolescents in Cape Town, South Africa: Caregivers' experiences. Subst Abuse Treat Prev Policy [Internet]. 2017 Mar; [cited 2017 Dec 14]; 12(1):18. Available from: https://www.ncbi.nlm.nih.gov/ pubmed/28347349

26. Pegoraro RF, Caldana RHL. Sofrimento psíquico em familiares de usuários de um Centro de Atenção Psicossocial (CAPS). Interface (Botucatu) [Internet]. 2008 Apr/Jun; [cited 2017 Dec 14]; 12(25):295307. Available from: http://www.scielo.br/scielo.php?script=sci_ arttext\&pid=S1414-32832008000200006\&lng=en. http://dx.doi. org/10.1590/S1414-32832008000200006

27. Chen F, Liu G. The health implications of grandparents caring for grandchildren in China. J Gerontol B Psychol Sci Soc Sci [Internet] 2012 Jan; [cited 2016 Aug 14]; 67B(1):99-112. Available from: http:// www.ncbi.nlm.nih.gov/pmc/articles/PMC3267025/

28. Carthron DL, Busam MR. The diabetic health of african american grandmothers raising their grandchildren. Clin Med Insights Womens Health [Internet]. 2016 Jun; [cited 2016 Jul 14]; 9(Supp 1):41-6. Available from: https://www.ncbi.nlm.nih.gov/pmc/articles/ PMC4927041/

\footnotetext{
a The "problematic" term refers to when the psychoactive substances consumption affects negatively, be it on an occasional basis or chronic, in one or more areas of the life of a person (physical, psychological and mental, social, schooling, labor or legal).

${ }^{\mathrm{b}}$ When the caregiver forget about itself in dedicating integrally to the grandson psychoactive substances-dependent.
} 